\title{
HUBUNGAN ANTARA STATUS GIZI, ANEMIA, STATUS INFEKSI, DAN ASUPAN ZAT GIZI DENGAN FUNGSI KOGNITIF PADA ANAK SEKOLAH DASAR DI DAERAH ENDEMIK GAKI
}

\author{
Toto Sudargo ${ }^{1}$, Emy Huriyati ${ }^{1}$, Lastiana Safitri', Winda Irwanti', Sri Ahadi Nugraheni² \\ 1) Prodi Gizi Kesehatan Fakultas Kedokteran Universitas Gadjah Mada \\ 2) Magister Gizi Fakultas Kesehatan Masyarakat Universitas Diponegoro \\ toto_sudargo@yahoo.co.id
}

\begin{abstract}
Anak-anak yang tinggal di daerah GAKI mempunyai risiko yang lebih tinggi untuk mengalami kelaparan dan rendahnya skor IQ. Tujuan penelitian ini menjelaskan hubungan status gizi, anemia, status infeksi, dan asupan zat gizi (energi, protein, karbohidrat, lemak, iodium, vitamin $\mathrm{C}$, vitamin $\mathrm{A}, \mathrm{Fe}, \mathrm{Zn}$, dan Selenium), dengan fungsi kognitif anak sekolah dasar (SD) yang tinggal di daerah GAKI, dan mengetahui kandungan iodium pada tanah dan air di wilayah tersebut. Jenis studi observasional dengan desain crosssectional. Subjek penelitian anak SD berusia 9-12 tahun kelas 3, 4, dan 5 dari 3 SD di daerah endemik GAKI Kecamatan Kismantoro, Kabupaten Wonogiri, Jawa Tengah. Status GAKI diukur menggunakan metode palpasi dan Urinary lodine Excretion (UIE), status gizi dengan indikator TB/U, status anemia menggunakan Hemocue, status infeksi dengan wawancara pada orangtua, asupan zat gizi menggunakan multiple food recall 24 jam (3 hari), kandungan iodium dalam tanah dan air menggunakan Inductive Coupled Plasma-Mass Spectrometry (ICP-MS) dan fungsi kognitif menggunakan Weschler Intelligence Score for Children-Revised (WISC-R). Hasil menunjukkan 20 subjek (28,9\%) mengalami GAKI, 27 subjek $(39,1 \%)$ stunting, 17 subjek $(24,6 \%)$ anemia, 11 subjek $(15,9 \%)$ infeksi (ISPA dan diare) dan 57 subjek $(82,6 \%)$ mengalami gangguan fungsi kognitif. Analisis bivariat menunjukkan tidak terdapat hubungan signifikan antara status GAKI dan infeksi dengan fungsi kognitif ( $p>0,05)$. Terdapat hubungan signifikan antara status gizi dan anemia dengan fungsi kognitif $(p<0,05)$. Analisis multivariat asupan zat gizi energi, protein, karbohidrat, lemak, iodium, vitamin $\mathrm{C}$, vitamin $\mathrm{A}$, besi, dan selenium memberikan kontribusi sebesar $20,9 \%$ dari skor IQ total anak sekolah. $\mathrm{Hb}$, UIE, dan asupan zat gizi memberikan kontribusi sebesar $24,1 \%$ dari skor IQ total anak sekolah. Hasil laboratorium menunjukkan rerata kandungan iodium tanah $(2,49 \mathrm{ppm})$, dan dalam air $(2,7 \mathrm{ppb})$ berada di bawah standar. Jadi status gizi dan anemia, asupan zat gizi berhubungan dengan fungsi kognitif anak sekolah. GAKI dan status infeksi tidak berhubungan dengan fungsi kognitif. Secara bersama $\mathrm{Hb}$, UIE dan asupan zat gizi berhubungan dengan fungsi kognitif. Rerata kandungan iodium pada tanah dan air di wilayah penelitian berada di bawah standar.
\end{abstract}

Kata kunci: GAKI, status gizi, anemia, infeksi, fungsi kognitif

\section{ABSTRACT}

\section{THE RELATIONSHIP BETWEEN NUTRITION STATUS, ANEMIA AND INFECTION STATUS, NUTRITION INTAKE TO THE COGNITIVE FUNCTION AMONG ELEMENTARY STUDENTS} IN ENDEMIC IDD AREA

Children who live in IDD area have higher risk in famine and lower achievement for IQ score test. The objectives of this research were describing the relationship between nutritional status, anemia, infection status, dietary intake of nutrients and cognitive function of elementary school children who live in IDD endemic area, and to know the iodine content on soil and water. This study was an observational with cross-sectional design. The subject of this research was school children at the third, fourth and fifthgrade in 3 different elementary schools located in Kismantoro District, Wonogiri Regency, Central Java, Indonesia. The criterion was children aged $9-12$ years. Totally, there were 69 subjects. Palpation method and Urinary lodine Excretion (UIE), measurement of Height for Age (HAZ), anemia by using Hemocue, infection status through interviewing, dietary intake in 3 days $\times 24$ hours food recall method, iodine content in soil and water analysed by Inductive Coupled Plasma-Mass Spectrometry (ICP-MS) and cognitive function by Weschler Intelligence Score for Children-Revised (WISC-R). The results showed that there was a significant relationship between nutritional status and anemia with cognitive function $(p<0,05)$. Using multivariate analysis, dietary intake of energy, protein, carbohydrate, fat, iodine, vitamin $C$, vitamin $\mathrm{A}, \mathrm{Fe}$, and selenium contributed $20.9 \%$ of total IQ Score of school-children. $\mathrm{Hb}$, UIE, and dietary intake contributed $24.1 \%$ to total IQ Score of school-children. The laboratory result showed the average of iodine in soil and water (2,49 ppm and 2,7 ppb, respectively), which were below the standard. In conclusion, there was a significant relationship between nutritional status and anemia to cognitive 
function. No significant relationship between IDD and infection status to cognitive function. Dietary intake of nutrients is associated to the cognitive function. In addition, $\mathrm{Hb}$ and $\mathrm{UIE}$, and dietary intake are associated to the cognitive function. Average of iodine content in soil and water are indicated below the standard.

Key words: IDD, nutritional status, anemia, infection status, cognitive function

\section{PENDAHULUAN}

G angguan akibat kekurangan iodium (GAKI) adalah gangguan tubuh manusia yang disebabkan oleh kurangnya iodium dalam tubuh sehingga tubuh tidak dapat memproduksi hormon tiroid. Kekurangan hormon tiroid dapat menyebabkan tiroid, hipertiroid, gangguan reproduksi, kematian bayi dan rendahnya status sosialekonomi seseorang. ${ }^{1}$ Lebih dari 1,9 milyar orang termasuk 285 juta anak-anak mengalami kekurangan asupan iodium. ${ }^{2}$ Berdasarkan studi observasi pada anak yang tinggal di daerah GAKI, ditemukan bahwa defisiensi iodium dapat menyebabkan penurunan fungsi kognitif. ${ }^{3}$

Berdasarkan penelitian di Asia Tengah dan Kaukasian, endemik GAKI akan menyisakan permasalahan sosio-ekonomi. ${ }^{4}$ Permasalahan sosio-ekonomi ini mempunyai peran yang penting dalam pola makan dan status gizi. ${ }^{5}$ Penelitian di Jakarta menunjukkan bahwa pada beberapa keluarga dengan ekonomi randah mengalami defisiensi asupan pada beberapa zat gizi ${ }^{6}$, di samping kemiskinan yang menjadi faktor utama dari malnutrisi. ${ }^{7}$ Buruknya status gizi berpengaruh pada kemampuan anak untuk merespon infeksi dan menggunakan energi serta zat gizi lain secara efektif. ${ }^{8}$ Indonesia masih menghadapi beberapa masalah infeksi dan malnutrisi yang keduanya itu saling berhubungan. Hal ini yang menjadi penyebab tidak dapat meningkatkan status kesehatan masyarakat Indonesia secara signifikan. Setiap tahun, tidak kurang dari 11 juta bayi dari seluruh dunia meninggal karena infeksi saluran pernapasan akut (ISPA), diare, malaria, dan campak. Ironisnya, 54 persen dari kematian tersebut berhubungan dengan kasus rendahnya status gizi. ${ }^{9}$

Meskipun dalam kondisi rendah atau sedang, malnutrisi mempunyai efek kesehatan fisik, gangguan kemampuan belajar, dan kehidupan sosial. Sebagian besar kasus malnutrisi disebabkan oleh defisiensi kalori, yang menyediakan energi dan protein untuk pembentukan sel tubuh. Gizi kurang merupakan indikator yang umum digunakan pada anak yang mempunyai tinggi badan dan berat badan di bawah kriteria normal. Hal ini disebabkan oleh kekurangan beberapa zat gizi esensial, dan bukan hanya energi dan protein saja. ${ }^{10}$

Defisiensi dari beberapa mikronutrien misalnya vitamin $\mathrm{A}$, zat besi, iodium dan zat zinc mempunyai implikasi pada kerusakan fungsi kognitif.3,11 Defisiensi zat besi adalah salah satu penyebab anemia yang berdampak pada fungsi kogntiif, Selain itu berpengaruh pada perilaku sosial dan emosional. Dilaporkan bahwa sekitar 33 persen anak sekolah di dunia mengalami defisiensi zat besi. Penurunan fungsi kognitif hingga -1 SD berkorelasi dengan riwayat anemia pada bayi dan anak sekolah dasar. ${ }^{12}$ Kelompok yang rentan terhadap anemia adalah anak-anak, remaja, wanita hamil dan menyusui, dan pekerja dengan penghasilan rendah (buruh). Kekurangan zat besi termasuk dalam 4 masalah gizi utama di Indonesia. ${ }^{13}$

Pada umumnya, masalah GAKI banyak terjadi di pegunungan, karena produksi pangan tergantung pada produksi lokal, yang tumbuh di tanah dengan kandungan iodium yang rendah. ${ }^{13}$ GAKI mempunyai hubungan yang erat dengan lokasi geografis di suatu area. Masalah ini banyak terdapat di wilayah pegunungan seperti Himalaya, Alpen, Andes, dan di Indonesia misalnya di Bukit Barisan, Sumatera, dan Pegunungan Kapur di selatan Jawa. Wonogiri termasuk dalam area Pegunungan Kapur selatan Jawa dan telah ditemukan sejak lama bahwa area-area tersebut merupakan daerah endemik GAKI. ${ }^{14}$ Gangguan akibat kekurangan iodium merupakan permasalahan serius dan mempunyai efek langsung pada kehidupan manusia. Kelompok yang rentan pada efek dari GAKI adalah wanita usia subur dan hamil, anakanak dan anak usia sekolah. ${ }^{15}$

Penelitian ini dilakukan di pegunungan berkapur, tepatnya di Kecamatan Kismantoro, Kabupaten Wonogiri, Jawa Tengah. Berdasarkan laporan dari Dinas Kesehatan Wonogiri, pada tahun 2006 terdapat kasus GAKI sebesar 21,2 persen (sedang). Tujuan penelitian untuk mengetahui hubungan dari 
GAKI, status gizi, anemia, status infeksi, dan asupan zat gizi dengan fungsi kognitif pada anak SD yang tinggal di daerah endemik GAKI, dan juga untuk mengetahui kandungan iodium pada tanah dan air sebagai faktor risiko dari GAKI.

\section{METODE PENELITIAN}

Penelitian ini adalah penelitian observasional dengan desain cross-sectional. Populasi adalah anak SD yang tinggal di Kecamatan Kismantoro, Kabupaten Wonogiri, Jawa Tengah. Pemilihan sampel anak SD menggunakan purposive sampling dengan kriteria inklusi anak SD berusia 9-12 tahun dan tinggal di Kecamatan Kismantoro. Besar sampel minimal ditentukan berdasarkan rumus Lemeshow (1987) untuk desain cross sectional. Selanjutnya dengan menggunakan metode simple random sampling didapatkan 71 subjek penelitian namun 2 orang tidak memenuhi kriteria inklusi sehingga akhirnya diperoleh 69 subjek penelitian.

Variabel bebas pada penelitian ini adalah status GAKI, status gizi, anemia, status infeksi, dan asupan zat gizi. Status GAKI diukur menggunakan metode palpasi dan UIE. Status gizi diukur menggunakan antropometri dengan indikator TB/U. Status anemia diukur dengan menganalisa haemoglobin $(\mathrm{Hb})$ menggunakan metode hemocue. Status infeksi diketahui dengan wawancara terstruktur kepada orang tua subjek dan asupan zat gizi diukur menggunakan multiple food recall 24 jam selama 3 hari. Variabel tergantung dalam penelitian ini adalah fungsi kognitif, diukur oleh psikolog menggunakan metode Wechsler Intelligence Scale for Children (WISC-R). Kandungan iodium dalam air dan tanah sebagai faktor geografis diukur dengan Inductive Coupled Plasma-Mass Spectrometry (ICP-MS) dalam laboratorium. Data secara statistik diolah menggunakan uji statistik chi square, fisher's exact, pearson's correlation, dan regression yang diolah menggunakan software komputer.
HASIL

Subjek penelitian sejumlah 69 dari 71 subjek yang memenuhi kriteria inklusi dan mengikuti hingga akhir penelitian. Mereka adalah siswa dari $3 \mathrm{SD}$, yaitu SD Miri 1, SD Pucung 1 dan SD Pucung 2. Anak sekolah adalah siswa kelas 3,4 , dan 5 , dengan usia 9 12 tahun, sebanyak 34 adalah laki-laki dan 35 adalah perempuan.

\section{Status GAKI}

Terdapat 20 dari 69 subjek yang menderita GAKI. Hal ini berarti Total Goiter Rate (TGR) untuk Kecamatan Kismantoro, Kabupaten Wonogiri adalah 28,9 persen. Menurut WHO, kecamatan ini termasuk dalam wilayah dengan endemik GAKI sedang. TGR anak sekolah biasa digunakan sebagai indikator GAKI pada suatu area. ${ }^{16}$

Status GAKI dengan indikator UIE dikatagorikan dalam 6 tingkat, berat $(<20 \mu \mathrm{g} / \mathrm{L})$, sedang $(20-49,9 \mu \mathrm{g} / \mathrm{L})$, ringan $(50-99.9 \mu \mathrm{g} / \mathrm{L})$, normal (100-199.9), risiko Idiopathic Intracranial Hypertension (IIH) (200-299.9), dan Isolated risiko Hypogonadotropic Hypogonadism $(\mathrm{IHH})$ (>300). Ditemukan bahwa tidak ada subjek yang mengalami GAKI berat, 6 subjek GAKI sedang (8.7\%), 13 subjek GAKI ringan (18.8\%), 39 subjek (39.1\%) normal, 17 subjek berisiko $\mathrm{IIH}(24.6 \%)$, dan 6 subjek berisiko $\mathrm{IHH}(8.7 \%)$. Secara rinci dapat dilihat pada Gambar 1.

\section{Status Gizi berdasarkan TB/U}

Status gizi dalam penelitian ini dinilai menggunakan indikator tinggi badan menurut umur (TB/U), dihitung skor persentil-nya, dan dikatagorikan sebagai stunted dan normal. Jika persentil adalah $\geq 5$, maka subjek dikatagorikan sebagai normal, sedangkan kurang dari 5 termasuk stunted. Tinggi badan diukur dengan menggunakan microtoise dengan akurasi 0,1 $\mathrm{cm}$. Jumlah subjek stunted sebanyak 27 anak $(39,13 \%)$ dan subjek dengan status gizi normal sebanyak 42 anak (60, 87\%). 


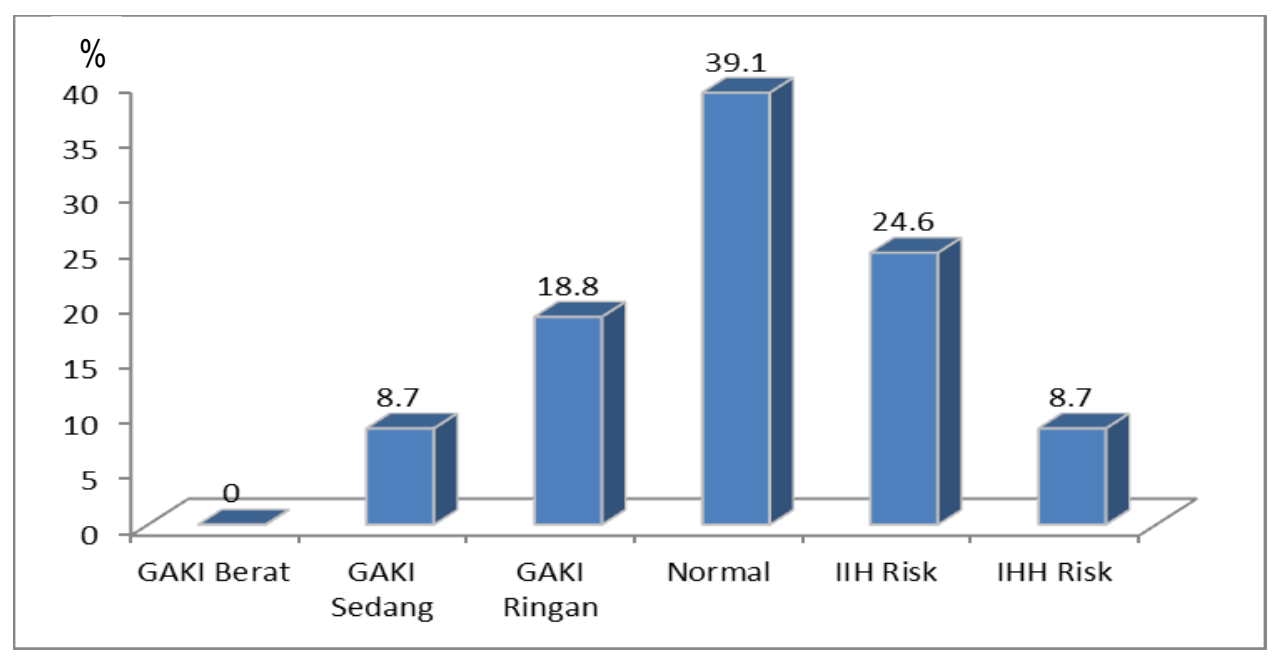

Gambar 1

Prevalensi GAKI anak SD di Kecamatan Kismantoro berdasarkan UIE

\section{Status Anemia}

Dalam penelitian ini, ditemukan bahwa sebesar $17(24,64 \%)$ subjek mengalami anemia dengan $\mathrm{Hb}$ kurang dari $11 \mathrm{mg} / \mathrm{dl}$, dan 52 (75,36\%) subjek mempunyai $\mathrm{Hb}$ normal.

\section{Status Infeksi}

Infeksi yang diperiksa dalam penelitian ini adalah diare dan ISPA. Subjek dikatakan diare jika pernah mengalami persisten diare selama lebih dari 14 hari. Informasi tentang diare dan ISPA diketahui dari wawancara terstruktur kepada orangtua subjek. Sebesar 11 anak (16\%) mengalami infeksi dan 58 anak lainnya (84\%) tidak mengalami infeksi.

\section{Fungsi Kognitif}

Rata-rata skor IQ total adalah 73.15 ( \pm 14.8$)$. Skor IQ ini terdiri dari dua macam skor, yaitu IQ verbal dan IQ non-verbal. Rata-rata IQ verbal adalah 73,09 $( \pm 14,6)$ dan non verbal adalah 78,07 $( \pm 14,1)$. Hasil dari skor IQ ini dikatarogikan sebagai normal dan abnormal. Skor normal dari fungsi kognitif adalah lebih besar atau sama dengan 90 and abnormal jika skor IQ adalah kurang dari 90 . Subjek dengan fungsi kognitif normal adalah sebanyak 12 $(17,3 \%)$ dan subjek dengan fungsi kognitif abnormal adalah 57 anak (82,6\%).

\section{Asupan Zat Gizi}

Asupan energi, protein, iodine, vitamin $\mathrm{C}$, vitamin $\mathrm{A}, \mathrm{Fe}$, dan $\mathrm{Zn}$ berada di bawah Angka Kecukupan Gizi (AKG), sementara asupan selenium berada di atas AKG. Rata-rata asupan energi adalah $1075,4 \mathrm{kkal}(52.46 \%)$, asupan protein adalah 28,11 (56,24\% AKG), iodium adalah $71,90 \mu \mathrm{g}(59,92 \%$ AKG), vitamin C adalah $23,3 \mathrm{mg}(46,62 \%$ AKG), zat besi adalah $4,87 \mathrm{mg}(38,57 \%$ AKG), zinc adalah $3,6 \mathrm{mg}$ $(25,71 \%$ AKG), dan selenium adalah $52.8 \mathrm{~g}$ (130.95\%) sebagaimana tergambar dalam Gambar 2.

\section{Kandungan iodium dalam tanah dan air}

Kandungan iodium pada tanah di daerah penelitian ini adalah 2,59 ppm yang termasuk dalam katagori rendah. Kandungan iodium normal dalam tanah adalah 100-150.000 ppm. Hasil ini sesuai dengan Fuge (2005) yang menyatakan bahwa di area pegunungan, kandungan iodium dalam tanah adalah rendah karena adanya cleaning/washing yang terjadi di dataran yang lebih tinggi lagi, yang menyebabkan rendahnya persediaan iodium pada area dibawahnya. Hal ini juga terjadi di pegunungan Himalaya dan Alpena. ${ }^{17}$

Kandungan iodium dalam air yang diambil dari dua sumber air yang biasa digunakan sebagai sumber air minum masyarakat di daerah ini adalah sebesar 2,7 ppb. Hasil ini termasuk dalam katagori rendah berdasarkan Lin, et al (2004), yang menyatakan bahwa kandungan normal iodium adalah 0,02 - 2 ppm. Lokasi sumber air berada pada daerah tinggi dan rendah. Hasil menunjukkan bahwa air dari daerah yang tinggi mengandung iodium lebih rendah dibanding di bawahnya. ${ }^{18}$ 


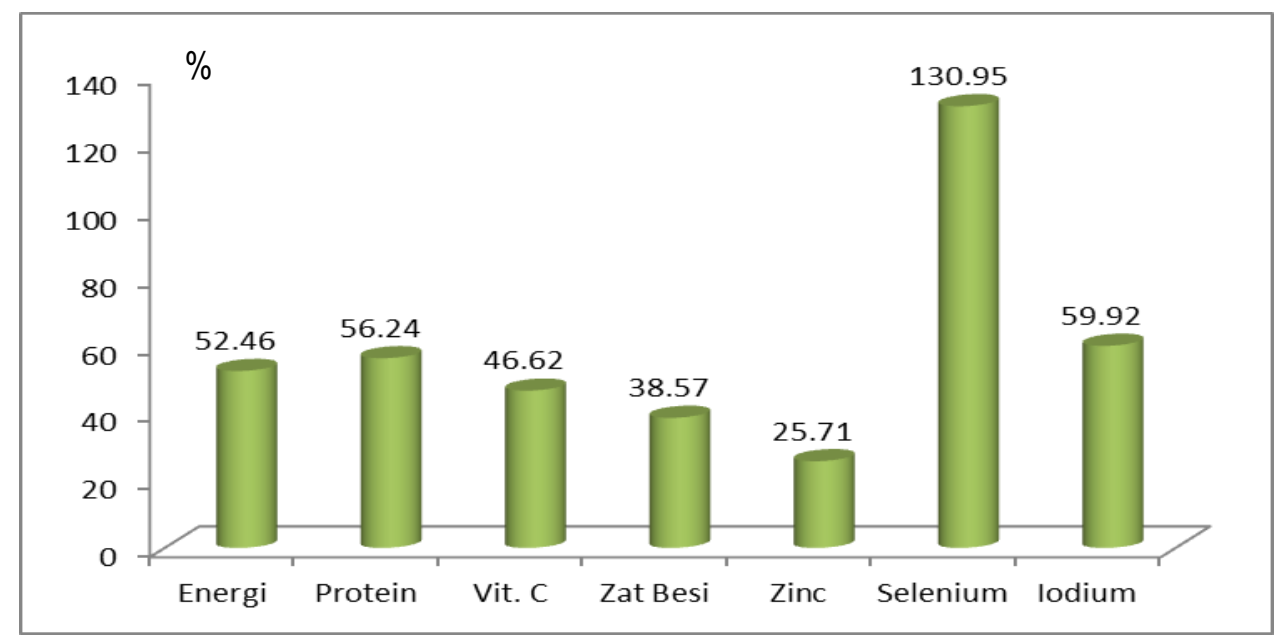

Gambar 2

Asupan Zat Gizi Dibandingkan dengan Angka Kecukupan Gizi untuk Anak Indonesia Usia 9-12 tahun

Hubungan antar variabel

Hubungan Status GAKI dengan Fungsi Kognitif

Dalam penelitian ini, ditemukan bahwa tidak terdapat hubungan yang signifikan antara status GAKI dengan palpasi dengan fungsi kognitif dengan $p=0,713(p>0,05)$ dan $r=0,045$.

\section{Hubungan Status Gizi dengan Fungsi Kognitif}

Hasil menunjukkan bahwa terdapat hubungan yang signifikan antara status gizi dengan fungsi kognitif $(p<0,05)$. Odds Ratio (OR) adalah 9,226 $(1,116-76,282)$ berarti bahwa subjek dengan stunted berisiko mengalami penurunan fungsi kognitif sebesar 9,226 kali lebih besar dibandingkan dengan subjek normal.

\section{Hubungan Anemia dengan Fungsi Kognitif}

Dalam penelitian ini ditemukan bahwa terdapat hubungan yang signifikan antara anemia dengan fungsi kognitif, ditunjukkan dengan nilai $p=0,047(p<0,05)$ dan $r=0,231$.

\section{Hubungan Status Infeksi dengan Fungsi Kognitif}

Hasil menunjukkan bahwa tidak terdapat hubungan yang signifikan antara status infeksi dan fungsi kognitif $(p>0,05)$ dengan Odds Ratio sebesar 2,340 $(0,270<0 R<20,252)$.

Tabel 1

Hubungan antara Status Gizi dan Fungsi Kognitif

\begin{tabular}{|c|c|c|c|c|c|c|}
\hline \multirow{2}{*}{\multicolumn{2}{|c|}{ Status Gizi }} & \multicolumn{2}{|c|}{ Fungsi Kognitif } & \multirow{2}{*}{ Jumlah } & \multirow{2}{*}{$p$} & \multirow{2}{*}{ Odds Ratio } \\
\hline & & Abnormal & Normal & & & \\
\hline \multirow[t]{3}{*}{ Stunted } & within stunted & $\begin{array}{c}26 \\
96.3 \%\end{array}$ & $\begin{array}{c}1 \\
3.7 \%\end{array}$ & $\begin{array}{r}27 \\
100 \%\end{array}$ & $\begin{array}{l}0.021 \\
(0<0.05)\end{array}$ & $\begin{array}{l}9,226 \\
(C l=1.116-76.282)\end{array}$ \\
\hline & & $37,7 \%$ & $1,4 \%$ & $39,1 \%$ & & \\
\hline & & 31 & 11 & 42 & & \\
\hline \multirow[t]{2}{*}{ Normal } & within normal & $73,8 \%$ & $26,2 \%$ & $100 \%$ & & \\
\hline & & $44,9 \%$ & $15,9 \%$ & $60,9 \%$ & & \\
\hline \multirow[t]{2}{*}{ Jumlah } & & 57 & 12 & 69 & & \\
\hline & & $82.6 \%$ & $17,4 \%$ & $100 \%$ & & \\
\hline
\end{tabular}


Tabel 2

Hubungan antara Status Infeksi dan Fungsi Kognitif

\begin{tabular}{|c|c|c|c|c|c|c|}
\hline & \multirow{2}{*}{ Status Infeksi } & \multicolumn{2}{|c|}{ Fungsi Kognitif } & \multirow{2}{*}{ Jumlah } & \multirow{2}{*}{$\mathrm{p}$} & \multirow{2}{*}{ Odds Ratio } \\
\hline & & Abnormal & Normal & & & \\
\hline \multirow{3}{*}{ Infeksi } & \multirow{3}{*}{ within infection } & 10 & 1 & 11 & 0,674 & 2,340 \\
\hline & & $90,9 \%$ & $9,1 \%$ & $100 \%$ & $(p>0.05)$ & $(\mathrm{Cl}=0,270-20,252)$ \\
\hline & & $14,5 \%$ & $1,4 \%$ & $15,9 \%$ & & \\
\hline \multirow{3}{*}{ Non-infeksi } & \multirow{3}{*}{ within non infection } & 47 & 11 & 58 & & \\
\hline & & $81 \%$ & $19 \%$ & $100 \%$ & & \\
\hline & & $68,1 \%$ & $15,9 \%$ & $84,1 \%$ & & \\
\hline \multirow{2}{*}{ Jumlah } & & 58 & 11 & 69 & & \\
\hline & & $82,6 \%$ & $17,4 \%$ & $100 \%$ & & \\
\hline
\end{tabular}

Hubungan antara asupan zat gizi dengan fungsi kognitif

Berdasarkan analisis korelasi, bahwa terdapat hubungan yang signifikan antara energi, protein, lemak, iodine, dan zinc dengan skor IQ Total. Sedangkan karbohidrat, vitamin $C$, vitamin A, Fe dan Se menunjukkan tidak berhubungan secara signifikan dengan skor $I Q$ Total (Tabel 3).

Tabel 3

Analisis Korelasi antara Asupan Zat Gizi dengan Fungsi Kognitif

\begin{tabular}{ll}
\hline Zat Gizi & Sig $(p)$ \\
\hline Energi & $0,045^{*}$ \\
Protein & $0,033^{*}$ \\
Karbohidrat & 0,168 \\
Lemak & $0,009^{*}$ \\
lodium & $0,038^{*}$ \\
Vitamin C & 0,223 \\
Vitamin A & 0,446 \\
Fe & 0,310 \\
Zn & $0,002^{*}$ \\
Se & 0,146 \\
\hline$\left.{ }^{*}\right)$ korelasi signifikan pada $p<0,05$ &
\end{tabular}

Seperti ditunjukkan pada Tabel 4, menggunakan analisis regresi menunjukkan hasil R-square=0,209. Hal ini menunjukkan bahwa asupan zat gizi energi, protein, iodium, vitamin $\mathrm{C}, \mathrm{Fe}, \mathrm{Zn}$ dan selenium memberikan pengaruh sebesar 20,9 persen dari total skor IQ. 
Gizi Indon 2012, 35(2):126-136 Hubungan antara status gizi, anemia Toto S., dkk.

Tabel 4

Analisis Regresi antara Asupan Zat Gizi dan Fungsi Kognitif

\begin{tabular}{lll}
\hline \multicolumn{1}{c}{ Zat Gizi } & Sig $(\mathrm{p})$ & R-Square \\
\hline Energi & 0,845 & 0,209 \\
Protein & 0,749 & \\
Karbohidrat & 0,873 & \\
Lemak & 0,726 & \\
lodium & 0,555 & \\
Vitamin C & 0,429 & \\
Vitamin A & 0,496 & \\
Fe & 0,155 & \\
Zn & 0,033 & \\
Se & 0,554 \\
\hline
\end{tabular}

Hubungan antara Hb, UIE, dan Asupan Zat Gizi dengan Fungsi Kognitif

Seperti ditunjukkan pada Tabel 5, menggunakan analisis regresi, secara bersama $\mathrm{Hb}$, UIE, dan asupan zat gizi menghasilkan R- square $=0,241$. Hasil ini menunjukkan bahwa $\mathrm{Hb}$, UIE, dan asupan zat gizi memberikan kontribusi sebesar $24,1 \%$ pada skor IQ Total anak SD yang tinggal di daerah dengan endemik GAKI.

Tabel 5

Analisis Regresi Hubungan Antara Hb, UIE, dan Asupan Zat Gizi dengan Fungsi Kognitif

\begin{tabular}{lcc}
\hline \multicolumn{1}{c}{ Variabel } & p & R Square \\
\hline UIE & 0,558 & 0,241 \\
$\mathrm{Hb}$ & 0,194 & \\
Energy & 0,845 & \\
Protein & 0,749 & \\
Lemak & 0,873 & \\
Karbohidrat & 0,726 & \\
lodium & 0,555 & \\
Vitamin C & 0,429 & \\
Vitamin A & 0,496 & \\
Fe & 0,155 & \\
Zn & 0,033 & \\
Se & 0,554 & \\
\hline
\end{tabular}




\section{BAHASAN}

Berdasarkan analisis statistik, telah diketahui bahwa tidak terdapat hubungan yang signifikan antara status GAKI dengan fungsi kognitif. Studi ini mempunyai hasil yang sama dengan penelitian yang dilaksanakan di Sukabumi, Jawa Barat. Pada awal penelitian, tes menggunakan WISC-R juga tidak menunjukkan hubungan yang signifikan dan pada akhir penelitian, semua kelompok menunjukkan peningkatan skor namun tidak terdapat perbedaan antar kelompok. ${ }^{19}$ Sebaliknya, hasil ini tidak sama dengan studi yang dilakukan di Spanyol pada tahun 2004, yang menunjukkan bahwa skor IQ pada anak di negara berkembang dipengaruhi oleh status GAKI. Nllai diatas median UIE $(150 \mu \mathrm{g} / \mathrm{dll})$ dapat meningkatkan skor $I Q$ anak sekolah dasar secara signifikan. ${ }^{20}$ Studi di Albania pada tahun 2005 menunjukkan bahwa GAKI berefek pada kognitif dan fungsi motorik. ${ }^{21}$

Perbedaan ini dapat disebabkan oleh karena perbedaan metode dalam penentuan status GAKI. Metode palpasi masih bergantung pada subjektivitas dari pemeriksa. Pengukuran kelenjar tiroid dengan ultrasound merupakan metode yang lebih baik, dimana metode ini menjadi referensi baru screening IDD pada ruang lingkup internasional. ${ }^{22}$

Analisis statistik menunjukkan bahwa terdapat hubungan yang signifikan antara status gizi dengan fungsi kognitif. Hal ini berarti bahwa subjek stunted mempunyai risiko yang lebih besar untuk mengalami fungsi kognitif yang abnormal bila dibandingkan dengan subjek normal. Hal ini sesuai dengan penelitian yang dilakukan pada 2131 anak di Filipina yang menunjukkan bahwa anak stunted pada usia dua tahun secara signifikan mempunyai skor kognitif yang lebih rendah dibandingkan dengan mereka yang tidak stunted. ${ }^{23}$ Penelitian lain menunjukkan bahwa anak yang stunting pada usia dua tahun mempunyai skor kognitif 10 poin lebih rendah (diukur dengan WISC-R) dibanding mereka yang tidak stunted. ${ }^{24}$

Penelitian yang dilakukan pada anak-anak Guatemala menunjukkan bahwa persediaan kalori berefek pada perkembangan kognitif termasuk perkembangan fisik dan status kesehatan secara umum. Persedian kalori dan protein yang tidak cukup akan merusak perkembangan sistem saraf otak. ${ }^{25}$ Penundaan perkembangan fisik dan mental anak, khususnya pertumbuhan otak dalam janin dapat berakibat pada intelegensi anak. ${ }^{26}$ Hubungan malnutrisi pada kecerdasan didasarkan pada fakta bahwa anak yang kekurangan asupan energi dan protein (protein-energy malnutrition/PEM), mempunyai berat otak 15-20 persen lebih ringan dibandingkan dengan bayi normal. Terlebih lagi, berat otak dapat 40 persen lebih ringan dibanding dengan bayi normal jika kekurangan energi dan protein berlangsung saat kehamilan. Oleh karena itu, anak-anak dengan energi dan protein dibawah normal, mempunyai skor IQ yang lebih rendah. Kemampuan abstrak, verbal, dan memori pada anak dengan PEM lebih rendah dibandingkan dengan mereka yang normal. ${ }^{27}$

Hubungan yang signifikan antara anemia dan fungsi kognitif pada studi ini sesuai dengan studi di Thailand pada tahun 2002. Penelitian tersebut menunjukkan bahwa terdapat hubungan antara fungsi kognitif dan nilai $\mathrm{Hb}$ pada darah antara subjek dengan status GAKI yang berbeda. ${ }^{28}$ Suplementasi zat besi pada anak sekolah dengan anemia dapat meningkatkan kemampuan belajar, ditandai dengan peningkatan prestasi belajar. ${ }^{29}$

Hubungan antara status infeksi dan fungsi kognitif sesuai dengan penelitian yang menunjukkan bahwa tidak terdapat hubungan yang signifikan antara diare dan fungsi kogntif yang diukur dengan menggunakan metode Wide Range Assessment of Memory and Learning atau WISC- III Mazes, namun skor untuk WISC-III Coding dan WISC-III Digit Span secara signifikan lebih rendah pada 17 anak yang mengalami diare persisten selama masa kanak-kanak. ${ }^{30}$ Subjek akan mempunyai fungsi kognitif yang baik jika mereka mempunyai persediaan zat gizi baik pula, kasih sayang dan perawatan orang tua, simulasi kognitif lebih awal, dan didukung dengan pendidikan dan kesejahteraan orang tua. Di sisi lain, subjek yang tidak menderita infeksi (diare dan ISPA) akan tetap mempunyai risiko rendahnya fungsi kognitif yang lebih rendah jika mereka kekurangan zat gizi, kasih sayang orang tua, stimulasi kognitif, dan tidak didukung oleh pendidikan dan kesejahteraan orang tua. Anakanak dengan kasih sayang orang tua, persediaan zat gizi dan stimulasi kognitif yang baik akan tumbuh dengan baik pula. ${ }^{27}$ Namun demikian, pada penelitian ini, faktor-faktor yang 
mempengaruhi fungsi kognitif tersebut tidak diinvestigasi. Penelitian lain menunjukkan bahwa tidak terdapat hubungan yang signifikan antara tes CPM dan tes verbal dengan lama hari atau episode diare persisten. ${ }^{31}$

Hubungan antara asupan zat gizi dan fungsi kognitif dalam studi ini dapat disebabkan oleh beberapa faktor, metode pengukuran food recall 24 jam lebih mengindikasikan asupan saat penelitian dilaksanakan, sementara fungsi kognitif merupakan proses elektrokimia dalam otak yang mempunyai hubungan yang erat dengan komposisi dan fisiologi otak. Menurut Bock dalam Hidajat, sel otak dibentuk sejak tiga bulan pertama kehamilan. Perkembangan ini terus berlanjut pada prenatal dan post-natal, hingga bayi berusia dua sampai dengan tiga tahun, dengan pertumbuhan cepat (growth spurt) pada 1 hingga 6 bulan pertama setelah kelahiran. Setelah itu, tidak ada lagi pertumbuhan kecuali pembentukan neuron baru dari sel yang telah mati. Dengan demikian diferensiasi dan perkembangan otak hanya tumbuh sampai dengan 3 tahun pertama kehidupan. Hal ini dapat menjelaskan bahwa masalah gizi karena pola makan yang buruk pada ibu hamil dan anak usia di bawah tiga tahun, mempunyai efek pada kualitas otak. Defisiensi zat gizi pada anak kurang dari dua tahun menyebabkan penurunan sel otak dari 15 hingga 20 persen. ${ }^{32}$

Faktor lain adalah bahwa WISC-R merupakan tes yang bias budaya. Penelitian di Amerika pada tiga grup etnik, (Anglo-American, Black, dan Mexican-American) dan pada dua kelas sosial, menunjukkan bahwa struktur keluarga dan ras berpengaruh terhadap hasil tes WISC-R. ${ }^{33}$ Hal ini berhubungan dengan Kismantoro yang terletak di daerah terpencil, jauh dari pusat ekonomi dan pemerintahan, sehingga kondisi budaya juga mempengaruhi hasil tes ini.

Pendidikan awal juga berpengaruh pada fungsi kognitif. Studi longitudinal oleh Palmer di Cali, menunjukkan bahwa suplementasi zat gizi tanpa inisiasi pre-school program, tidak mempunyai efek terhadap perkembangan psikologi yang diukur dengan tes kemampuan kognitif yang bervariasi dari usia 4 hinggal 7 tahun. Sementara kombinasi dari intervensi dan pendidikan mempunyai efek jika dimulai lebih awal dan dalam jangka waktu yang panjang. ${ }^{34}$

\section{SIMPULAN DAN SARAN}

\section{Simpulan}

Tidak terdapat hubungan yang signifikan antara status GAKI dan fungsi kognitif. Selain itu terdapat hubungan yang signifikan antara status gizi dan fungsi kognitif. Terdapat hubungan yang signifikan antara anemia dan fungsi kognitif. Tidak terdapat hubungan yang signifikan antara status infeksi dan fungsi kognitif. Haemonglobin $(\mathrm{Hb})$, EIU, dan asupan zat gizi berhubungan dengan Skor IQ Total. Kandungan iodium dalam tanah dan air di Kecamatan Kismantoro berada dibawah level normal.

\section{Saran}

Penentu kebijakan (Dinas Kesehatan atau Dinas Pendidikan pada level kabupaten) agar melaksanakan monitoring pertumbuhan anak secara periodik, misalnya sekali dalam tiga bulan. Sebagai tambahan, pemeriksaan $\mathrm{Hb}$ pada siswa juga agar dilaksanakan secara periodik, sebagai contoh 6 bulan sekali. Pemberian makanan tambahan dan pengukuran kandungan iodium dalam garam juga diperlukan dengan pertimbangan bahwa Kecamatan Kismantoro mempunyai kandungan iodium yang rendah pada tanah dan airnya. Agar dapat dilakukan penelitian selanjutnya yang menggunakan test tanpa bias budaya, seperti Culture-Free Intelligence Test (CFIT). Penilaian asupan zat gizi disarankan menggunakan metode yang menunjukkan intake masa lalu (jangka panjang) bila ingin melihat hubungannya fungsi kognitif, sebagai contoh Food Frequency (FFQ).

\section{UCAPAN TERIMA KASIH}

Terimakasih dan penghargaan yang setinggi-tingginya kami ucapkan kepada tim The Hi-Link Research Project: Agung Harijoko I Wayan Warmada, dan Dutha Widagdo; Puskesmas Kismantoro, Dinas Pendidikan Kecamatan Kismantoro Wonogiri, Jawa Tengah, semua guru dan siswa dari SD Pucung 1, SD Pucung 2 dan SD Miri 1.

\section{RUJUKAN}

1. Rusiawati, Yuyus dan Sutomo, $S$. Penanggulangan Gangguan Akibat 
Kekurangan lodium di Indonesia. Cermin Dunia Kedokteran. 1993;85: 47-51.

2. Zimmermann, M.B., Connoly, K., Bozo, M., Bridson, J., Rohner, F., Grimci, L. lodine Supplementation Improves Cognition in lodine-Sufficient Schoolchildren in Albania: A Randomized, Controlled, Double Blind Study. American Journal of Clininical Nutrition. 2006; 83:108-114.

3. Black, M. Micronutrient Deficiencies and Cognitive Functioning. The Journal of Nutrition. 2003; 133: 3927S-3931S.

4. Hadi, Hamam. Beban Ganda Masalah Gizi dan Implikasinya Terhadap Kebijakan Pembangunan Kesehatan Nasional. www.gizi.net. 2005.

5. Scrimshaw, N.S, SanGiovanni J.P. 1997. Synergism of Nutrition, Infection, and Immunity: on Overview. American Journal Of Clinical Nutrition. 1997: 66; 464S-477S.

6. Gerasimov, G. Overview of The Status of lodine Deficiency Disorders in The Countries of Central Asia, Turkey, and Azerbaijan. Moscow: ICCIDD (International Council for Control of lodine Deficiency Disorders); 1997.

7. Yang, Xilin, Bridget Hsu-Hage, Huiguang Tian, Gang Hu, Qina Dong, Junhua Wu, Mark L.W.The role of income and education in food consumption and nutrient intake in a Chinese population. Asia Pacific Journal of Clinical Nutrition. 1998: 7 (3/4);217-223.

8. Schultink, W, Gross R, Sastroamidjojo S, Karyadi. Micronutrients and urban life style: selected studies in Jakarta. Asia Pacific Journal of Clinical Nutrition. 1995: 5(3);145148.

9. Sheikholeslam, R, Z. Abdollahi, dan F.N. Haghighi. 2004. Managing nutritional programmes in developing countries.Eastern Mediteranian Health Journal. 2004:10(6); 737-746

10. Jukes, M. Early childhood health, nutrition and education. London: UNESCO; 2006.

11. Aboud, F.E. Cultural perspectives on the interactions between nutrition, health, and psychological functioning in Online Readings in Psychology and Culture Washington: Center for Cross-Cultural Research, Western Washington University; 2002.
12. Jukes, M., J. Mc Guire, Frank $M$, and Robert S. "Nutrition and Education." Nutrition: A Foundation for Development. Geneva: ACC/SCN; 2002.

13. Kodyat, B.A., Thaha, A.R.,Minarto. Penuntasan Masalah Gizi Kurang. Dalam: Prosiding Widyakarya Nasional Pangan dan Gizi VI 1998. Jakarta: LIPI; 1998.

14. Djokomoeldjanto, R. Hipotiroid di Daerah Defisiensi lodium. Dalam: Kumpulan Naskah Simposium GAKI, 35-46. Semarang: Badan Penerbit Universitas Diponegoro; 1993.

15. Jalal, F., and Sumali, M. A. Gizi dan Kualitas Hidup: Agenda Perumusan Program Gizi Repelita VII untuk Mendukung Pembangunan Sumber Daya Manusia yang Berkualitas. Dalam: Prosiding Widyakarya Nasional Pangan dan Gizi VI. Jakarta: LIPI, 1998.

16. Assessment of lodine Deficiency Disorder and Monitoring their Elimination, A Guide for Programme Managers, $2^{\text {nd }}$ Edition. Geneve: WHO; 2007.

17. Fuge, Ron. Soils and lodine Deficiency: Essentials of Medical Geology, Impacts of the Natural Environment on Public Health. Ed. Selinus, Aloway. New York: Elsevier Inc; 2005.

18. Lin, N.F., Tang J., and Bian J.M. Geochemical Environment and Health Problem in China. Netherlands: Kluwer Academic Publishers; 2004.

19. Saidin, M., Muherdiyantiningsih, Ridwan, E., Ihsan, N., Lamid, A., Sukati, and Karyadi, L. 2002. Efektifitas Penambahan Vitamin A dan Zat Basi pada Garam lodium terhadap Status Gizi dan Konsentrasi Belajar Anak Sekolah Dasar. Penelitian Gizi dan Makakan. 2002: 25; 14-25.

20. Fernandez, PS., Barahona, RT., Martinez, JAM., Martinez, GR., Fuentes, EG., Garriga, MJ., et al. Intelligence Quotient and lodine Intake: A Cross-Sectional Study in Children. The Journal of Clinical Endocrinology and Metabolism. 2004: 89 (8); 3851-3857.

21. Zimmermann, MB., Connolly, K., Bozo, M., Bridson, J., Rohner, F., and Grimci, L. lodine Supplementation Improves Cognitif 
in lodine-Deficient Schoolchildren in Albania: A Randomized, Controlled, Double-Blind Study. American Journal of Clinical Nutrition. 2006: 83; 108-114.

22. Zimmermann, MB, Hess, SY., Molinari, L., de Benoist, B., Delange, F., Braverman, LE., et.al 2004. New Reference Values for Thyroid Volume by Ultrasound in lodinesufficient Schoolchildren: a World Health Organization/Nutrition for OHealth and Development lodine Deficiency Study Group Report. American Journal Clinical Nutrition .2004:79;231-137.

23. Mendez, M.A and Adair, L.S. Severity and Timing of Stunting in The First Two Years of Life Affect Performance on Cognitive Tests in Late Childhood. The Journal of Nutrition. 1999: 125; 1555-1562.

24. Berkman, D.S, Lescano A.G, Gilman R.H, Lopez S.L, Black M.M. 2002. Effect of Stunting, Diarrhoeal Disease, and Parasitic Infection During Infancy on Cognition in Late Childhood: A Follow-up Study. The Lancet. 2002:359; 564-571.

25. Freeman, H.E, Robert E.Klein, Jerome Kagan, and Charles Yarbrought. Relations between Nutrition and Cognition in Rural Guetemala. American Journal Public Health. 1977: 67; 233-239.

26. Schorder, D.G. Malnutrition. Otawa: Human Press; 2001.

27. Andarwati. R., Endy. P., Indira, L., G. 2006. Hubungan Berat Badan Lahir, Pemberian ASI Eksklusif, Status Gizi dan Stimulasi Kognitif dengan Kecerdasan Anak Usia 5-6 Tahun. Jurnal Gizi Klinik Indonesia. 2006:2(3); 95-100.

28. Sungthong, R., Mo-suwan, L., and Chongsuvivatwong, V. 2002. Effect of Haemoglobin and Serum Ferritin on
Cognitive Function in School Children. Asia Pasific J Clin Nutr. 2002: 11(2);117-122.

29. Briel, TVD., West, CE., Bleichrodt, N., Vijver, FJR., Ategbo, EA., and Hautvast, JGAJ. Improved lodine Status is Associated with Improved Mental Performance of Schoolchildren in Benin. American Journal of Clinical Nutrition. 2000:72(5); 1179-1185.

30. Niehaus, M.D., Moore, S.R., Patrick, P.D., Derr, L.L., Lorntz, B., Lima, A.A., Guerrant, R.L. Early Childhood Diarrhae is Associated with DiminishedCognitive Function 4 to 7 Years Later in Children in A Northeast Brazilian Shantyown. American Journal of Tropical Medicine and Hygiene. 2002: 66(5); 590-593.

31. Tarleton, J.L, Haque, R., Mondal, D., Shu, J., Farr, B.M., Petri, W.A. Cognitive Effects of Diarrhea, Malnutritian, and Entamoeba histolytica on School Age Children in Dhaka, Bangladesh. The American Society of Tropical Medicine and Hygiene. 2006: 74(3):475-481.

32. Hidajat, Boerhan, Roedi I., dan Nurul H. Nutrisi dan Perilaku. Divisi Nutrisi dan Metabolik Bagian IImu Kesehatan Anak. Yogyakarta: UGM; s.n.

33. Oakland, Thomas and Feigenbaum, David. Multiple sources of test bias on the WISC-R and Bender-Gestalt Test. Journal of Consulting and Clinical Psychology.1979:48(2); 249-253.

34. Watanabe, Koichiro, Rafael F, Junko F and Lien Thi Huong Tran. 2005. Early Childhood Development Interventions and Cognitive Development of Young Children in Rural Vietnam. The American Society for Nutritional Sciences J. Nutr.2005: 135;1918-1925. 